\title{
The Challenges of Managing an Organisation during and after the Economic Crisis
}

Elizabeth Nambili Shatonhoka* and Rashad Yazdanifard

Centre of Post Graduate Studies, Limkokwing University of Creative Technology, Cyberjaya, Malaysia

*Corresponding author: Elizabeth Nambili Shatonhoka, Centre of Post Graduate Studies, Limkokwing University of Creative Technology, Cyberjaya, Malaysia, Tel: +60102065284; E-mail: nambiliabisai@gmail.com

Received date: December 06, 2014; Accepted date: January 20, 2015; Published date: January 30, 2015

Copyright: (c) 2015 Shatonhoka EN et al. This is an open-access article distributed under the terms of the Creative Commons Attribution License, which permits unrestricted use, distribution, and reproduction in any medium, provided the original author and source are credited.

\begin{abstract}
The past five years saw business sectors of the world wither a storm brought on by a global economic crisis, which started with American banks. This crisis left many companies and world economies limping. So far many organizations have faced the challenges of swimming through the waves of the crisis and trying to pick up the pieces after the economic downturn aftermath, amidst the doubts and uncertainty of whether the crisis is over. This paper aims to analyses and explain key challenges that companies experienced during and after the economic crisis.
\end{abstract}

Keywords: Challenges; Organizations; Global economic crisis

\section{Introduction}

2008 was a year that the world saw major economies experience a sudden economic downturn brought on by a financial crisis first experienced in the United States of America which than spread like flu to the rest of the world. Because of this credit crisis and meltdown in the USA, there was a worldwide reduction of overall spending which greatly affected the economies [1]. The financial crisis has also coincided with the third unfavorable movement, which is the slowdown of the economic circle [2]. The following few years saw many economies experience a recession. Some of the key features of this unfavorable period to many businesses and the economies of the world included, a negative or a very low growth, Raising unemployment, falling asset prices, raising inflation, a decline in real income and a reduction in spending by the consumers. The global economy experienced a 2.4 percent contraction in 2009. This picture spelled a general business cycle contraction and also presents great challenges in managing an organization during and after this crisis. Companies crave for a stable economic environment in which to plan and increase profitability. The reality is that, they are challenged by a whole range of small, medium and large opportunities and threats. This crisis affects and challenge businesses across the world. For some companies, they may spell doom or disaster while others; they may spell an opportunity that can be seized. Unfortunately, many companies did not strike favorable opportunities during the crisis, they were rather challenged with a duty of trying to save their companies from sinking. This paper aims to analyses the real challenges in managing an organization that is experiencing a reduction in the success of its business during the financial meltdown.

\section{The Challenge of Keeping Workers Motivated}

During this financial times difficulty; employees are worried about the safety of their jobs because the possibilities that their jobs are not safe seem to be high. This is especially true in the private sector. For the employers, keeping their employees calm and putting their psychologies at ease is a daunting task because the ongoing trend in the labour market of massively laying off workers is not helping the situation. Some companies might have the only option of cutting jobs to keep their company afloat, for the remaining employees it would be demoralising and keeping their morale boosted is challenging because they might be worried that their jobs are next to be cut. In hard economic times, when new ideas and positive behaviour could be most valuable, employees may not speak up they may be discouraged, leading to reduced employee participation, less organisational learning, less innovation and less receptiveness to change [3]. This is the behaviour of employees who feel as if they don't matter, the possibility of them being laid off is very high and there is no point in saying anything because things just don't look good. Downsizing does not happen to an organisation, managers opt for it in an attempt to save face [4]. Employees may feel because managers chose to lay their colleagues off or cut their salaries, they also don't value their feelings and opinions.

\section{Profits Declining}

The financial turmoil has plunged the sales revenues and profits of many companies into a decline, the companies will cut back on hiring new employees, or freeze hiring entirely in an effort to cut costs and improve the business performance, some companies might stop buying new equipment, conducting research and development and stop producing or coming up with new products. All this is crucial in the growth of sales revenue and market share. Many organisations might also reduce spending on marketing and advertising. Organisational resources (humans especially) did not significantly predict the impact of the economic crisis [5]. These cost-cutting measures affect other businesses, both big and small, which provide the goods and services used by the big manufacturer. SMEs have a flexibility and rapid ability to quickly respond to the business environmental needs, their ability to satisfy rapidly changing customer needs and their potential for close relationships with customers [6]. SMEs are very important for a business chain because they can quickly get close to the customers. They don't seem to be more significant like big companies, but if they are affected as a result, the smooth operations of the industry are greatly affected. Consumer spending which is the major driver of the business activities will also decline 
because of the effects of the recession. Economic crisis acts as an exogenous transitory shock, which mainly reduces the demand for goods and services [7]. Consumers' real income has decreased, prices have gone up, and their spending will also slow down as a result. A paradigm shift has also taken place, forcing people to evaluate their personal and household finances as well as their spending [8]. Some companies where not experiencing growth at all, they were just trying to stay in business and not go out of the game, but even that was difficult. No new client came to the market: growth was only possible at the expense of competitors and financial institutions where struggling to stay afloat as well [9]. This companies tried to follow what other companies did in older to survive.

\section{Falling Stocks and Dividends}

When the declining revenues show up on the company's earnings report, the company's stock price may decline. Dividends may also fall, or disappear entirely. Shareholders may become dismayed. Global crisis may have a big effect on stock volatility behaviour [2]. When something is not right somewhere, fingers will have to be pointed at someone and this is the case all over the world following the 2008 financial meltdown. The shareholders and the board of directors may call for an entirely new senior management team. The company's advertising agency may be dumped and a new one hired. The advertising and marketing team may also face a reshuffle. During crises, stocks volatility register high levels and stock prices fall sharply in both developed and emerging markets [10]. When the company's stock falls and the dividends slump or stop, investors who hold that stock may sell and reinvest the yields into better-performing stocks. This will further depress the company's stock prices.

\section{The Reduction in the Quality of Goods and Services}

After the cost cutting measures, the value of goods and services produced by the recession-impacted manufacturers may decrease. In an attempt to cut costs to improve and save the business from bankruptcy, the company may compromise the quality and the desirability of its products and services. This poses a challenge for senior executives, who wish to remain at the competitive edge through technology innovation [11]. Human resources are a source of sustainable competitive advantage because they are a representation of unique skills that are difficult to duplicate and replace [8]. This is especially true because it is the human resources that give brain power to a company, which enables it to have that competitive advantage over others and make it possible to sustain that advantage throughout the years. This also enables them to keep and maintain their market share because after all, the workforce that they are trying to reduce is the one that presents quality to the consumers and quality generates customers.

\section{Creditors Taking Time to Pay or not Paying Up at All}

The Company's debtors are also affected by the recession. The company's customers that owe it money may take long to pay up or pay slowly, or not pay on time, they may only be able to pay a certain percentage, or they might not be able to pay up at all. This will affect the company's revenues, the revenues will be reduced and not coming in on time. The affected company also have their dues to settle and they will pay their bills slowly, partly and not on time. This will reflect badly on the company because unreliable payment tendencies will reduce the value of the company's ability to obtain and attract financing and investment. Consumers are reluctant to spend and banks and other financial institutions are also reluctant to lend [12]. This depicts the picture of the flow of the money in the economy which practically makes it challenging for anyone to pay their dues, consumers are reluctant to spend because there is little where the money is coming from and the banks and other financial institutions are also reluctant to loan them money because organisations that owe them are also not paying their dues on time or might be struggling to pay back their loans.

\section{Reduction of Access to Consumers}

Companies that are hit hard by the recession try to cut costs; they reduce spending on advertising and marketing. This will result in less access to consumers because the ways of making them aware of the firms goods or services, have been reduced. Consumers' confidence will also decline because of the effects of recession and their spending will drop. Falling sales and falling investments have an increasing effect on the economy [12]. When consumers see that the company's sales are declining and it is reducing some of its resources, like laying off its employees and seldom advertise its products, they might start thinking the company has gone out of business. They start forgetting the business and shift their royalty to another competitor. As a result, the business might find itself falling behind its competitors in the long run. Investments in marketing communication such as advertising are most important and essential to the successful outcomes during a recession.

\section{Managing an Organisation after the Recession}

Companies in the world are still working on their recovery strategies after the 2008 financial crisis. Many have learned the lesson and put strategies in place to ensure that they don't repeat the same mistakes again. But the challenges after the crisis leans more towards the uncertainty, the doubt, and the reforms. This is all proving to be slowing down the recovery.

\section{Coping and running a business with lesser resources}

Getting back to its absolute sales and revenues before the crisis is the biggest trial of all trials that many companies have to face. Many organisational processes face different pressures to change and adapt to new circumstances [8]. The aim is to manage the business through the recession successfully and see it back to its glorious years again, but that can prove to be challenging, since many businesses have reduced their workforce and reduced on less essential projects and many other growth factors, to cut costs. As one of the important stakeholders, employees are a crucial strategic resource to the firm's success [13]. This may mean that companies are not guaranteed to move ahead when the recovery starts, maybe they will fall behind their competitors. Some economic experts are of the opinion that the crisis is not yet over or that it is too early to declare an end to it. Because of this uncertainty, companies may find themselves not sure of what strategies to employ. Some companies might have to restructure and remake their organisations to cope with the new business environment that the crisis has presented [14]. Pointed out that business model innovation rennovations is the most challenging strategy for incumbent companies. Many companies might have to prove this prediction to be true because this may mean changing their company from a product company to a service company and the likelihood of success for this kind of change is not guaranteed. 


\section{Recapturing consumer's confidence in the company}

Consumers are loyal to companies that convince them with their good reputation. With the recent economic downturn, a lot of companies had to be faced with a lot of struggles, cutting salaries of their employees, laying off workers, declining profits and productivity. This kind of picture does not reflect well on the reputation of any company. On the contrary, it will only kill the confidence consumers have in the company. The crisis have reduced or removed consumer's confidence and emotion to act irrational when spending. [14] argued that it seems that even after the eventual economic recovery, increased uncertainty and volatility will remain permanent features of the business environment. This is proving to be true because consumers have tightened their financial belts and will not easily spend their money because they are preparing themselves just in case another crisis comes back. Some lost their jobs and they are cautioning their spending. Though the world economy may begin to recover, consumer confidence will not be easily gained back because they are still feeling the hangover of the crisis and feel that it still lingers in some areas. It is possible for companies to still have consumer confidence back, provided that these companies start performing the way they performed before the crisis. There are still a lot of problems and challenges in some sectors [15]. Some sectors' performance might affect consumers' confidence in the company even if it might not be doing badly. Cutting resources and costs beyond limits, however can have negative, long-term consequences and must be avoided [16]. Companies need to be cautious of cutting too much cost and in the process; they cut resources which are vital to their long-term growth and recovery.

\section{Possible reluctance and inability to lend, of financial institutions}

Financial institutions that finance businesses will be stricter in financing new projects or turn around strategies that companies might employ to try and recover from the crisis and attempt to expand their business operations again. These institutions have also felt the pinch of the financial crisis and they are taking precautions. They would not prefer to finance a company that has decreasing sales revenues and have not been making profit for the past financial years. This will not help businesses and they will not recover quickly or they might not recover at all. They might be left with other options like merging with other companies to try and survive. Most major financial institutions were severely weakened and impaired [17]. The sentiments echoed by these authors also reflect and confirm that financial institutions also have battles of their own to fight. Many Banks and Financial institutions found themselves struggling and unable to pay their creditors and depositors since many of the assets they were holding where either worthless or worth a fraction of their book value [12]. The aftermath of the crisis left some financial institutions challenged in their capabilities to finance and assist companies trying to recover from this economic crisis. Small business growth and entrepreneurship are regarded as essential drivers for economic recovery [18]. SMEs tend to encounter declines to their request for funds in many instances, this does not help giant companies recover fast since SMEs contribute to their growth and they are not getting much help from financial institutions.

\section{Discussions}

The world economic crisis saw many companies facing bankruptcy, a setback in their business growth and an uncertain future. Managers of companies had to take measures, some more drastic than others, to try and save these companies. The real challenge is in trying to save face and keep their companies afloat during the crisis and after the crisis and at the same time trying to get their companies to their previous sales revenues and profits before the financial crisis hit them. During this financial storm, businesses have taken cost-reduction measures that affected employees, advertising and marketing. As a result, these organisations have experienced a real challenge in keeping their employees motivated after employing these cost-reduction measures which involves the employees. Accessing consumers through advertising and marketing became a challenge. Profits and share prices fell. This cost reduction measures also affected the quality of the goods manufactured and services produced by affected companies. The crisis in general negatively affected the stock returns. Stock volatility registered high levels in both developed and emerging markets. The repercussions of the financial crisis on businesses are so great that they are still lingering years after the crisis, when the economies are recovering. The mistrust and the doubt among the consumers and other stake holders are still there. Consumers are cautious of spending because of a possibility that the crisis is not completely over and history has a habit of repeating itself. Business financiers might be stricter on businesses that are struggling to recover and those that fall behind their competitors because of the crisis. All this is not helping companies recover and regain their previous favourable spot on the business scene. Some companies that were not affected severely seem to be recovering fast and those that were hit hard are experiencing a slow recovery.

\section{Conclusion}

The 2008 economic downturn spread across the world like a wild fire with no one to put it out immediately. Economies of the world and all their key players were affected. From rich consumers, poor consumers, big companies, small companies, Banks to governments and their politics. Companies in the world especially in the capitalist countries were affected severely. The policies and strategies that were employed to save these companies were challenging and contradicted the growth of many companies. They sometimes diverted the consumer spending choice, decreased the confidence of the consumers and killed the morale of the employees who are crucial to the survival of any organisation. There is uncertainty among the consumers and financial institutions weather the crisis is really over or it might just return, just when they are letting their guards down, they are being cautious in their lending and spending habits just in case it is not over yet. These behaviours are not helping companies recover fast. Some companies are more likely to be faced with the solution of changing cause by restructuring their entire organisation and changing from either a service producing company to a manufacturing company or from manufacturing to providing services. Some companies are faced with the hurdle of expanding their companies again and catching up with their competitors.

\section{Acknowledgements}

The author would like to thank GOD almighty for giving her the strength and seeing her through the process of writing this paper. She is also directing her gratitude to her lecture, Dr Rashad Yazdanifard, for assisting and directing her in the writing of this paper. Finally, she is thanking her fellow MBA students for encouraging her and assisting her in putting together this writing. 
Citation: Shatonhoka EN, Yazdanifard R (2015) The Challenges of Managing an Organisation during and after the Economic Crisis. Int J Econ and Manage Sci 4: 222. doi:10.4172/2162-6359.1000222

Page 4 of 4

\section{References}

1. Carty R, Weiss G (2012) Does CEO duality affect corporate performance? Evidence from the USA banking crisis. Journal of financial regulations and compliance 20: 26-40.

2. Fillipov S, Kalatoy K (2011) Global crisis and activities of Multinational enterprises in new EU member states, International journal of emerging markets 6: 304-328.

3. Scholosser F, Zolin R (2012) Hearing voice and silence during stressfull times. Employee relations 34: 555-573.

4. Appelbaum H, Paton E, Shapiro B(2003) The early retirement incentive program: A downsizing. Journal of the European industrial training 27: 22-35.

5. Arevalo J, Aravind D (2012) The impact of the crisis on Corporate Responsibility: The case of UN global compact participants. Corporate Governance 10: 406-420.

6. Parry S, Jones R, Rowley J, Teahan B (2012) Marketing for survival: a comparative case study of SME software firms. Journal of small business and enterprise development 19: 712-728.

7. Crimman A, Wiebner F, Bellmann L (2012) Resisting the Crisis: Short time work in Germany. International journal of manpower 33: 877-900.

8. Brencic M, Pfaijfar G, Raskovic M (2012) Managing in a time of crisis: Marketing, HRM and innovation. Journal of business and industrial marketing 2716: 436-446.

9. Jaakson K, Reino A, Motsmees P (2012) Basic journal management. 7: 202-216.
10. Al-RJoub S, Azzam H (2012) Financial Crisis, Stock returns and volatility in an emerging stock market: the case of Jordan. Journal of economic studies 39: 178-211.

11. Weerakkody V, Currie W, Ekanakale (2003) Re-engineering business process through application service providers. Business process management 9: 776-794.

12. McDonell A, Burgess $J$ (2013) The impact of the global financial crisis on managing employees, International journal of manpower, 34(3):184-197.

13. Li J, Hung K, Tangpong C (2012) The role of agent conscientiousness and reciprocity norm in employee layoff decisions. Management research review 35: 419-440.

14. Reeves J, Deimler S (2009) Strategies for winning in the current and postrecession environment. Strategy and Leeadership 37: 10-17.

15. Curwen $P(2005)$ The post-recession structure of the telecommunications sector takes shape. Info 17: 52-65.

16. Kailasam M, Johri L, Wongsurawat W (2013) Weathering the downturn Strategic Direction 29: 34-37.

17. Appelbaumm H, Keller S, Arvares H, Bedard C (2012) Organisational crisis: Lessons from Leehman Brothers and Paurson \& Company. International Journal of commerce and management 22: 285-305.

18. Price L, Rae D, Cini V (2013) SME perceptions of and responses to the recession. Journal of small business and entrepreneurship 20: 484-502. 